\title{
SĄDOWNICTWO POWSZECHNE W II RZECZYPOSPOLITEJ (1917-1939). ZAŁOŻENIA ORGANIZACYJNE, BUDOWA STRUKTUR, FUNKCJONOWANIE
}

\section{Lech Krzyżanowski}

http://orcid.org/0000-0003-2042-046X

Uniwersytet Śląski w Katowicach

\author{
ABSTRACT \\ THE JUDICIARY SYSTEM IN THE SECOND REPUBLIC OF POLAND \\ (1917-1939): ORGANISATIONAL ASSUMPTIONS, STRUCTURES, \\ FUNCTIONING
}

The standardisation of legal provisions regulating the functioning of the judiciary system was one of the key challenges faced by the Second Republic of Poland at the dawn of its independence. The law that had been created by the partitioners was still used in the first years of interwar Poland. A regulation uniform for the whole country: the Law on Common Courts Organisation, had not entered into force until 1929. Under that regulation, women could enter the profession of judge for the first time in the country's history. This must be recognized as one of the greatest achievements of interwar Poland, whereas one of its significant failures were the low salaries that hindered the functioning of the courts. Judges had protested against that throughout the interwar period, but they did not manage to gain any considerable pay increase. The 1930s also saw a dispute over judicial independence. The adherents of Józef Piłsudski, who ruled Poland at the time, tried to gain control over the judiciary system, which was perceived by the majority of judges as an attempt to limit their rights. Despite those turbulences, the assessment of actions taken in regard to the judiciary system in the interwar period should be positive. The functioning of the courts achieved a definitely higher level compared to the time before World War I.

Keywords: judge, judiciary system, judicial independence, court, jurisdiction, judgement, judicature.

Słowa kluczowe: sędzia, wymiar sprawiedliwości, niezawisłość sędziowska, sąd, jurysdykcja, wyrok, orzecznictwo sądowe.

Zdecydowana większość agend państwa polskiego datuje początek swej XX-wiecznej działalności na jesień 1918 lub pierwsze miesiące 1919 roku. Niepodległy wymiar sprawiedliwości jest tu wyjątkiem. Uruchomienie sądów (zwanych 
początkowo Królewsko-Polskimi) miało bowiem miejsce wcześniej, jeszcze w 1917 roku. Do tej daty odwoływano się podczas rocznicowych uroczystości w okresie międzywojennym, tamtymi wydarzeniami uzasadniano również obchody stulecia wymiaru sprawiedliwości w 2017 roku. Brak jakiegokolwiek protestu w tej sprawie, zarówno dawniej, jak i współcześnie, pozwala przyjąć, iż uznanie 1917 za rok narodzin polskiego suwerennego sądownictwa nie wzbudza żadnych kontrowersji.

Wcześniejsze uruchomienie polskich sądów niż samo uzyskanie niepodległości było skutkiem planów, jakie wobec ziem polskich zaboru rosyjskiego sformułowały rządy państw centralnych w akcie 5 listopada. Obiecując utworzenie niepodległej Polski, Niemcy i Austro-Węgry poczuły się w obowiązku zainicjować proces tworzenia instytucji, które o wspomnianej niepodległości miały zaświadczać. Do takich należały między innymi sądy. Z tego powodu, pod koniec stycznia 1917 roku, powołano do życia Departament Sprawiedliwości Tymczasowej Rady Stanu Królestwa Polskiego (dalej TRS) i postawiono mu zadanie w postaci uruchomienia sądów Królewsko-Polskich na obszarze przyszłej Polski. Działania takie w połowie 1917 roku podjął dyrektor Departamentu Sprawiedliwości Stanisław Bukowiecki. Z jego inicjatywy TRS wydała wiele rozporządzeń stanowiących podstawę normatywną dla powstających wówczas sądów. Największe znaczenie miało rozporządzenie z 17 lipca 1917 roku zawierające przepisy tymczasowe o urządzeniu sądownictwa w Królestwie Polskim ${ }^{1}$. Uzupełniającą rolę odegrały inne rozporządzenia: na przykład o dyslokacji sądów Królewsko-Polskich, o wynagrodzeniu urzędników wymiaru sprawiedliwości, o kosztach sądowych. Po wydaniu tych aktów prawnych oraz obsadzeniu właściwymi siłami fachowymi uruchamianych sądów możliwe stało się uroczyste zainicjowanie polskiego wymiaru sprawiedliwości. Nastąpiło to 1 września 1917 roku, biorąc zaś pod uwagę składane wówczas deklaracje, doskonale zdawano sobie sprawę z epokowego znaczenia ówczesnych wydarzeń2 ${ }^{2}$

Tworząc kolejne jednostki polskiego wymiaru sprawiedliwości w części byłego zaboru rosyjskiego, starano się utrzymać dotychczasową, znaną miejscowej ludności strukturę i nazewnictwo sądów. W ten sposób unikano zamieszania, które z pewnością dałoby o sobie znać, gdyby zastosowano nowe, nieznane tu rozwiązania formalne. W efekcie przesądzono o dalszym funkcjonowaniu sądów pokoju, sądów okręgowych oraz dwóch sądów apelacyjnych, w Warszawie i w Lublinie. Zupełnie nową instytucją był jedynie Sąd Najwyższy ${ }^{3}$. Pełnił funkcję kasacyjną wobec wyroków sądów apelacyjnych, a ponadto zapewniał jednolitość orzekania, co nie było wcale łatwe, zważywszy na to, iż obszar apelacji warszawskiej podlegał niemieckim,

\footnotetext{
${ }^{1}$ Dziennik Urzędowy Departamentu Sprawiedliwości 1917 Nr 1, poz. 1.

2 Archiwum Akt Nowych, Tymczasowa Rada Stanu, sygn. 60, mf B7569, Protokół aktu otwarcia sądów Królewsko-Polskich, s. 3-4; E.S. R a p p a p o r t, Pierwociny polskiego sądownictwa państwowego (1916-1917) (Szkic historyczny), „Demokratyczny Przegląd Prawniczy” 1947, nr 9, s. 3-7; M. Materniak-Pawłowska, Departament Sprawiedliwości Tymczasowej Rady Stanu i poczatki Ministerstwa Sprawiedliwości (luty 1917-październik 1918), „Czasopismo Prawno-Historyczne” 2006, z. 2, s. 249 272; eadem, Sądy Królewsko-Polskie (1917-1918), „Czasopismo Prawno-Historyczne” 2007, z. 1, s. 87-91.

${ }^{3}$ Sąd Najwyższy wykonywał zadania, które w Austro-Węgrzech zastrzeżono dla Najwyższego Trybunału Sądowego i Kasacyjnego w Wiedniu, a w Niemczech dla lipskiego Sądu Rzeszy Niemieckiej.
} 
a lubelskiej - austriackim władzom okupacyjnym. Sąd Najwyższy pierwotnie składał się z dwóch izb - karnej i cywilnej, z czasem jego struktura powiększała się, podobnie jak liczba zatrudnionych pracowników. Według danych z 1 lipca 1918 roku pracowało tam 10 sędziów, 2 prokuratorów, 2 podprokuratorów oraz ponad 20 urzędników różnego szczebla. Sąd Najwyższy szybko okazał się niezbędny dla polskiego wymiaru sprawiedliwości. Kolejnymi aktami prawnymi nie tylko więc utrzymano istnienie, ale też sukcesywnie zwiększano jego znaczenie orzecznicze ${ }^{4}$. Prestiż, nieodłącznie związany z tym urzędem, miał swe źródło między innymi w autorytecie, jakim obdarzono kolejnych prezesów Sądu Najwyższego. Przez cały okres międzywojenny byli to bez wyjątku prawnicy o ogromnej wiedzy fachowej i znaczącym dorobku zawodowym. W 1917 roku pierwszym prezesem Sądu Najwyższego został Stanisław Pomian Srzednicki. Po przejściu w stan spoczynku, w 1922 roku, zastąpił go Franciszek Nowodworski, dwa lata później wybrano Władysława Seydę, a w ostatnim dziesięcioleciu II Rzeczypospolitej funkcję pierwszego prezesa Sądu Najwyższego sprawował Leon Supiński. Jedynie ostatnia zmiana podyktowana była względami wzbudzającymi kontrowersje. Władysław Seyda został mianowicie odwołany jako nie dość gorliwy wykonawca poleceń władzy sanacyjnej. Nawet w tym wypadku jednak zadbano, by jego następca miał ugruntowaną pozycję w środowisku prawniczym i zasłużenie cieszył się jej szacunkiem ${ }^{5}$.

Kolejne kroki, jakie podejmowano w celu utworzenia ogólnopolskiej struktury wymiaru sprawiedliwości, odbywały się równocześnie z przyłączaniem do państwa polskiego kolejnych ziem. Jesienią 1918 roku, w chwili notyfikowania mocarstwom zachodnim faktu istnienia suwerennej Polski, sądownictwo tego państwa działało jedynie w apelacji warszawskiej i lubelskiej. Od 1 stycznia 1919 roku polski wymiar sprawiedliwości rozciągnął swe kompetencje na zachodnią Galicję. Na tym terenie, początkowo, sędziowie podporządkowali się władzy Polskiej Komisji Likwidacyjnej, uznając, iż ewentualne zaakceptowanie zwierzchnictwa Ministerstwa Sprawiedliwości wymaga wcześniejszych negocjacji. Takie odbyły się w Warszawie 28 grudnia 1918 roku z udziałem ówczesnego ministra sprawiedliwości L. Supińskiego oraz prezesów sądów krajowych wyższych: z Krakowa - Władysława Woltera oraz ze Lwowa - Adolfa Czerwińskiego. Na tej podstawie 31 grudnia 1918 roku Tymczasowy Naczelnik Państwa wydał dekret o przejęciu sądownictwa w byłym zaborze austriackim, co mimo wszystko spotkało się z wyrazami niezadowolenia ze strony niektórych sędziów ${ }^{6}$. Ostatecznie jednak przeważyło pragnienie wpisania się w polski system wymiaru sprawiedliwości. W styczniu 1919 roku ziściło się to

${ }^{4}$ Dnia 8 II 1919 r. wydano dekret w przedmiocie ustroju Sądu Najwyższego. Dziennik Praw Państwa Polskiego (dalej: Dz.P.P.P.) 1919, nr 15, poz. 199, stanowiący w okresie międzywojennym podstawowy akt prawny, określający zasady funkcjonowania tego organu władzy sądowniczej. O istnieniu Sądu Najwyższego przesądził później art. 84 konstytucji marcowej.

${ }_{5}^{5}$ M. Pietrzak, Sąd Najwyższy w II Rzeczypospolitej, „Czasopismo Prawno-Historyczne” 1981, z. 1, s. 83-90; B. Cy bulsk i, Sąd Najwyższy w latach 1917-1919, „Acta Universitatis Wratislaviensis” 2003, nr 2501, Prawo, CCLXXXV, s. 239; M. Materniak-Pawłowska, Ustrój sądownictwa powszechnego w II Rzeczypospolitej, Poznań 2003, s. 71-73.

${ }^{6}$ Dz.P.P.P. 1918, nr 23, poz. 76. 
jednak tylko w odniesieniu do apelacji krakowskiej. Bardziej skomplikowana sytuacja panowała we wschodniej Galicji, czyli, biorąc pod uwagę strukturę sądownictwa polskiego, w apelacji lwowskiej. Zawarta w dekrecie z 31 grudnia 1918 roku informacja o przejęciu przez państwo polskie sądów także na tym terenie była raczej wyrazem politycznych pragnień niż stwierdzeniem faktu. We wschodniej Galicji trwały w tym czasie walki polsko-ukraińskie, zatem do przejęcia sądownictwa przez II Rzeczpospolitą było jeszcze daleko. Ostatecznie Polska objęła nad tymi terenami władzę, co (niezależnie od obietnicy ustanowienia tam autonomii) było równoznaczne z rozpoczęciem działalności przez polskie sądownictwo. Konflikt militarny przesądził również o włączeniu do II Rzeczypospolitej części Śląska Cieszyńskiego. Po chwilowym, jak się okazało, przejęciu przez Polskę zwierzchnictwa nad większością tego terenu, co było efektem umowy między Radą Narodową Śląska Cieszyńskiego a Zemským Národním Výborem pro Slezsko, uruchomiono na Śląsku Cieszyńskim polskie sądy. Jednak już w pierwszej połowie 1919 roku polscy sędziowie z większości placówek na tym terenie zostali usunięci, gdy sporną ziemię zajęła armia czeska. Dopiero w 1920 roku, po podziale Śląska Cieszyńskiego między oba państwa, polskie sądy w okręgu cieszyńskim znalazły się w strukturze wymiaru sprawiedliwości II Rzeczypospolitej. Tym samym jednak przestały działać na Zaolziu, na którym pojawią się ponownie dopiero w $1938 \mathrm{roku}^{7}$.

Wytyczanie polskiej granicy zachodniej wyznaczało kolejność tworzenia polskiego wymiaru sprawiedliwości w byłej dzielnicy pruskiej. Zwycięskie dla strony polskiej powstanie wielkopolskie, a następnie, warunkowana przez ten militarny sukces, decyzja zapisana $\mathrm{w}$ traktacie wersalskim pozwoliły objąć w posiadanie Wielkopolskę i część Pomorza Gdańskiego. Tym samym mógł się rozpocząć proces tworzenia na tym obszarze polskiego sądownictwa, które korzystając z sieci pruskich placówek wymiaru sprawiedliwości, było gotowe niemal natychmiast rozpocząć swą pracę, pod warunkiem wszakże znalezienia odpowiedniej liczby polskich sędziów. Jak będzie o tym mowa w dalszej części artykułu, nie było to zadanie proste, ale jednak okazało się wykonalne. W rezultacie na przełomie 1919 i 1920 roku nastąpiło oficjalne przejęcie sądownictwa na opisywanym terenie. W służbie polskiej zameldowały się wówczas sądy na terenie kolejnych dwóch okręgów apelacyjnych, w Poznaniu i Toruniu. Trzeci okręg apelacyjny, utworzony na terenie byłej dzielnicy pruskiej, objął przyznaną Polsce część Górnego Śląska wespół z opisanym już Śląskiem Cieszyńskim. Tworzenie polskiej struktury sądownictwa na Górnym Śląsku przeciągnęło się aż do 1922 roku, ponieważ długo niewyjaśniona pozostawała kwestia przebiegu na tym terenie granicy polsko-niemieckiej. Trzy powstania śląskie oraz plebiscyt zadecydowały ostatecznie o podziale spornego obszaru. W apelacji katowickiej, poza jednym sądem apelacyjnym (z siedzibą w Katowicach), znalazły się dwa sądy okręgowe (w Katowicach i w Cieszynie) oraz 15 sądów powiatowych (11 w części

${ }^{7}$ Archiwum Narodowe w Krakowie (dalej: ANK), Zespół: Sąd Apelacyjny w Krakowie, sygn. 163a II, Minister Sprawiedliwości z 5 I 1919 r. do W. Woltera, prezesa Sądu Krajowego Wyższego w Krakowie, bp.; L. Krzyża now ski, Właczanie krakowskiego okręgu sądowego do struktur wymiaru sprawiedliwości II Rzeczypospolitej. Geneza, przebieg i skutki, „Krajowa Rada Sądownictwa” 2017, nr 3, s. 44-47; Sądownictwo na Spiszu i Orawie, „Przegląd Sądowy” 1920, nr 12, s. 18. 
górnośląskiej, 4 w części cieszyńskiej). Po przejęciu sądownictwa przez Polskę symbolicznie utworzono jeden zupełnie nowy sąd powiatowy, z siedzibą w Rudzie, by w ten sposób zademonstrować, iż państwo polskie bardziej troskliwą opieką otoczy swych obywateli (w tym wypadku skracając drogę petentów do sądu), niż czynili to dawniej Niemcy ${ }^{8}$.

W tym samym czasie gdy polskie sądy rozpoczynały swą działalność na Górnym Śląsku, do II Rzeczypospolitej został włączony jeszcze jeden region - Wileńszczyzna. Tym samym także i tam, czyli biorąc pod uwagę strukturę wymiaru sprawiedliwości, w apelacji wileńskiej, rozpoczęto proces tworzenia polskich sądów. Apelacja wileńska jako ostatnia weszła w skład II Rzeczypospolitej, aczkolwiek polskie sądy na tym terenie funkcjonowały już od 1919 roku, po otwarciu, 26 września 1919 roku, sądu apelacyjnego w Wilnie. Wcześniej, w czerwcu, uruchomione zostały sądy okręgowe w Wilnie i w Grodnie, we wrześniu w Łucku, a w październiku w Mińsku Litewskim. Początkowo jednak ich działalność utrudniały zawirowania polityczne i militarne, których skupienie na Wileńszczyźnie było szczególnie duże. Z tego powodu zresztą uruchomiono w Warszawie Sąd Apelacyjny Ziem Wschodnich, działający do 1 lipca 1922 roku. Jego likwidacja oraz włączenie Litwy Środkowej w skład państwa polskiego oznaczały pełne ustabilizowanie się struktury wymiaru sprawiedliwości na tym terenie?.

Biorąc pod uwagę cały obszar II Rzeczypospolitej, w chwili gdy budowę struktury wymiaru sprawiedliwości można było uznać za ukończoną, czyli w 1922 roku, na terenie kraju działały 774 sądy powszechne, w których pracowało nieco ponad 4000 sędziów. Organizację sądownictwa tworzyło 8 sądów apelacyjnych z siedzibami w Warszawie, Lublinie, Wilnie, Krakowie, Lwowie, Poznaniu, Toruniu i w Katowicach, 50 sądów okręgowych oraz nieco ponad 700 sądów pierwszej instancji, zwanych, w zależności od dzielnicy, sądami powiatowymi lub pokoju. Po wejściu w życie prawa o ustroju sądów powszechnych będą to sądy grodzkie. Wypada tu zwrócić uwagę, że toruński okręg apelacyjny wraz z sądem apelacyjnym znajdującym się w tym mieście zostały w 1933 roku zlikwidowane z przyczyn ekonomicznych. Okręg toruński został wówczas włączony w obręb apelacji poznańskiej. Protesty miejscowej inteligencji oraz poprawa ogólnej sytuacji gospodarczej w kraju po ustąpieniu kryzysu spowodowały podjęcie prac nad przywróceniem apelacji ${ }^{10}$. $\mathrm{W}$ tym celu w Toruniu rozpoczęto nawet budowę obszernego gmachu, który miał

\footnotetext{
${ }^{8}$ Archiwum Państwowe w Poznaniu, Sąd Apelacyjny w Poznaniu, sygn. 129, Departament Sprawiedliwości Ministerstwa byłej Dzielnicy Pruskiej z 1 XII 1919 r. do Jana Motty’ego delegata tego ministerstwa, k. 1; Archiwum Państwowe w Katowicach, Naczelna Rada Ludowa, sygn. 277, sędzia Tadeusz Stark z 24 III 1922 r. do Wydziału Administracyjnego NRL, k. 16; T. Zając zkowski, Szkic historyczny organizacji sądownictwa polskiego w bytej dzielnicy pruskiej od czasów rewolucyjnych $1918 \mathrm{r}$. [w:] Zbiór rozporządzeń i okólników Ministerstwa byłej Dzielnicy Pruskiej z roku 1920 mających znaczenie dla wymiaru sprawiedliwości, Poznań 1921, s. 8; L. Krzyżanowski, Sędziowie w II Rzeczypospolitej. Okręgi apelacyjne: krakowski i katowicki. Katowice 2011, s. 92-97; B. Cy bu1ski, Geneza polskiego sądownictwa na Górnym Śląsku (1920-1922), „Studia Śląskie” 1990, t. 98, s. 120-137.

${ }^{9}$ K. Petrusewicz, Dziesięciolecie sadownictwa polskiego na Ziemiach Wschodnich, Wilno 1929, s. 3-7; M. Materniak-Pawłowska, Ustrój..., s. 92-99.

${ }^{10}$ Dziennik Ustaw Rzeczypospolitej Polskiej (dalej: Dz.U. RP) 1938, nr 26, poz. 229.
} 
służyć potrzebom miejscowego sądu apelacyjnego. Na przeszkodzie ukończeniu prac budowlanych i reaktywowaniu apelacji toruńskiej stanął wybuch II wojny światowej. W okresie międzywojennym zmalała również liczba sądów okręgowych, do 45, więcej pojawiło się za to sądów grodzkich (wzrost o około 5\%). To ostatnie związane było między innymi z zajęciem Zaolzia w 1938 roku. Struktura polskiego wymiaru sprawiedliwości powiększyła się wówczas o 6 sądów grodzkich oraz o 30 etatów sędziowskich. Był to najwyższy jednostkowy wzrost liczebności środowiska sędziowskiego w okresie międzywojennym. Pod koniec lat 30. liczba sędziów była mniej więcej równa tej, która charakteryzowała opisywaną grupę dwadzieścia lat wcześniej ${ }^{11}$.

Problemy, jakie musiało rozwiązać polskie sądownictwo u zarania II Rzeczypospolitej, miały dwojaki charakter. Po pierwsze, należało jak najprędzej uruchomić poszczególne placówki polskiego sądownictwa, a to wymagało znalezienia dla nich polskiej obsady personalnej. Po drugie, analogicznie do innych gałęzi prawa, pilnym wyzwaniem było ujednolicenie przepisów normujących strukturę oraz sposób funkcjonowania wymiaru sprawiedliwości. Trudno było zaakceptować stan, w którym na terenie jednego państwa o docelowo unitarnej strukturze funkcjonować będą sądy odmienne co do nazwy, statusu prawnego orzekających w nich sędziów, stosowanej procedury itp.

Znaczenie pierwszej kwestii miało swe źródło w polityce niemieckiego i rosyjskiego zaborcy. Ci niechętnie zgadzali się na zatrudnianie w charakterze sędziów osób polskiego pochodzenia. Niezmienna praktyka władz w tym zakresie doprowadziła do stanu, w którym jeśli Polacy decydowali się na podjęcie studiów prawniczych, plany życiowe wiązali najczęściej z wolnymi zawodami, przede wszystkim $\mathrm{z}$ adwokaturą. Jedynie administracja austriacka nie uzależniała pracy $\mathrm{w}$ sądownictwie od narodowości kandydata. W rezultacie chętnie studiowali prawo, a następnie zostawali sędziami Polacy, Rusini, Żydzi, korzystając z oferty edukacyjnej uniwersytetów w Krakowie, we Lwowie, a nawet w Czerniowcach. Wraz z powstaniem II Rzeczypospolitej sędziowie niepolskiego pochodzenia, związani z administracją państw zaborczych, zaczęli być usuwani z wymiaru sprawiedliwości. Sporym kłopotem okazało się jednak zastąpienie ich Polakami. Tych bowiem ani w byłym zaborze pruskim, ani w rosyjskim nie było. Nieliczni polscy adwokaci nie garnęli się do zasilenia sądownictwa już choćby ze względów finansowych. Jedynym rezerwuarem polskich sił fachowych okazała się Galicja, gdzie notowano wręcz nadmiar osób o wykształceniu prawniczym. W 1919 roku i w kilku następnych nastąpiły zatem liczne migracje galicyjskich sędziów do byłego zaboru rosyjskiego, a potem zwłaszcza do byłej dzielnicy pruskiej. W apelacji poznańskiej, pomorskiej i katowickiej w 1922 roku jedynie pojedynczy sędziowie byli miejscowego pochodzenia. Zdecydowana większość przybyła z Galicji. W dawnej dzielnicy rosyjskiej odsetek

${ }^{11}$ Dane dla 1922 r. na podstawie ANK, Sąd Apelacyjny w Krakowie, sygn. 377, Wykaz sądów Rzeczypospolitej Polskiej bp.; Dziennik Urzędowy Ministerstwa Sprawiedliwości 1923, nr 7, s. 173; Z. F e d o row i c z, Wypisy do nauki o Polsce wspótczesnej, Wilno 1923, s. 403. Należy jednak podkreślić, że w okresie, do którego odwołują się podane liczby, następowała spora fluktuacja zarówno sił sędziowskich, jak i liczby sądów. Liczby te traktować należy zatem jedynie orientacyjnie. 
migrantów nie był aż tak wysoki, ale i tu przeważająca część sędziów miała napływowy charakter. Podkreślić należy, iż decyzja o przenosinach nie należała do łatwych i początkowo niewielu galicyjskich sędziów decydowało się na taki krok. Oznaczał on bowiem konieczność zerwania dotychczasowych kontaktów towarzyskich i układania egzystencji w zupełnie nowym miejscu, bez zabezpieczenia w postaci mieszkania, kręgów przyjacielskich i sąsiedzkich itp. Zapał sędziów skutecznie hamowała także świadomość tego, że przenosząc się do innej dzielnicy, galicyjscy sędziowie będą zmuszeni przyswoić sobie nieznane im dotychczas przepisy proceduralne, a nim osiągną biegłość w posługiwaniu się nimi, znacznie więcej czasu będą musieli poświęcać obowiązkom zawodowym. To, że ostatecznie siłami galicyjskimi udało się obsadzić sądy we wszystkich dzielnicach II Rzeczypospolitej, wynikało przede wszystkim z poczucia obywatelskiej odpowiedzialności i z patriotyzmu przenoszących się sędziów ${ }^{12}$.

Drugi z wymienionych problemów był oczywistą spuścizną czasu zaborów, gdy Prusy (Niemcy), Austro-Węgry oraz Rosja miały możliwość dowolnego kształtowania systemu wymiaru sprawiedliwości i definiowania jego miejsca w strukturze organów władzy. Pomijając wiele drobnych różnic, odnoszących się na przykład do poszanowania zasady niezależności sądów, sposobu dochodzenia do pełni praw zawodowych przez sędziów itp., wypada zwrócić uwagę na bodaj najwyraźniej ujawniającą się odmienność dotyczącą organizacji sądów pierwszej instancji w dzielnicy rosyjskiej. Działały tam mianowicie tzw. sądy pokoju oraz sądy gminne, w nich zaś nierzadko zatrudnione były osoby bez wykształcenia prawniczego, które swój urząd zawdzięczały głosom miejscowej społeczności. Struktura miejscowego sądownictwa oraz działalność wymiaru sprawiedliwości oparte tam były na przepisach z 1864 roku, funkcjonujących na ziemiach Królestwa Polskiego od 1876 roku. W odróżnieniu od dwu pozostałych zaborów na ziemiach byłej dzielnicy rosyjskiej najwcześniej, bo jeszcze w 1917 roku, wprowadzono przepisy polskie, o czym była już mowa. Nie doprowadziło to, co prawda, do całkowitego wyparcia ustawodawstwa rosyjskiego, niemniej w najważniejszych kwestiach umożliwiło spolszczenie wymiaru sprawiedliwości. W użyciu pozostała jednak formuła sądownictwa pierwszoinstancyjnego, realizowanego przez osoby bez wykształcenia prawniczego, za to cieszące się poważaniem w lokalnych społecznościach. Pomysł ten miał u zarania II Rzeczypospolitej wielu zwolenników, którzy chcieli nie tylko utrzymania go na terenie byłego zaboru rosyjskiego, ale nawet rozciągnięcia na resztę Polski. Podkreślali niski koszt pracy tak skonstruowanych sądów, łatwość znalezienia dla nich kadr „sędziowskich” oraz wysoki stopień akceptowania wyroków ferowanych przez osoby, które wcześniej znalazły uznanie w oczach miejscowych wyborców. Argumenty te przesądziły o ustanowieniu sądów pokoju tam, gdzie najtrudniej było o zawodowych sędziów,

12 Wznowienie sadownictwa państwowego polskiego (pięciolecie 1917-1922), Warszawa 1923, s. 32-33; B. Cybulski, Pomoc Małopolski i Wielkopolski w tworzeniu apelacji śląskiej (1920-1922), „Acta Universitatis Wratislaviensis" 1986, nr 823, Prawo, CXXXVII, s. 191-192. 
czyli w byłej dzielnicy pruskiej. Jednak gdy tylko sytuacja kadrowa na tym terenie poprawiła się, w drugiej połowie lat 20., z tej formy sądownictwa zrezygnowano ${ }^{13}$.

Podstawą prawną działalności sądów w dzielnicy pruskiej była ustawa o ustroju sądownictwa z 27 stycznia 1877 roku. Parokrotnie nowelizowana, stanowiła w pierwszych latach istnienia II Rzeczypospolitej normatywną bazę, na której opierała się działalność sądów w okręgach apelacyjnych: toruńskim, poznańskim oraz w katowickiej części okręgu śląskiego. Przewidywała strukturę wymiaru sprawiedliwości, na którą składały się sądy powiatowe jako sądy pierwszej instancji oraz sądy okręgowe. Te ostatnie były sądami odwoławczymi od wyroków sądów powiatowych, w przypadku zaś niektórych przestępstw oraz w odniesieniu do wybranych spraw cywilnych mogły funkcjonować jako sądy pierwszej instancji. Wówczas odwołania od ich wyroków rozstrzygały sądy apelacyjne, znajdujące się w wymienionych wyżej miastach. Na terenie byłego zaboru austriackiego największe znaczenie miała ustawa z 1 sierpnia 1895 roku o wykonywaniu sądownictwa i właściwości sądów zwyczajnych w sprawach cywilnych (tzw. norma jurysdykcyjna). Wraz z kilkoma innymi aktami prawnymi odpowiedzialnymi za funkcjonowanie sądownictwa, obowiązywała ona od 1 stycznia 1898 roku. Również na tym obszarze powstanie państwa polskiego nie wpłynęło na obowiązujący stan prawny. Norma jurysdykcyjna w pierwszych latach istnienia II Rzeczypospolitej określała sposób funkcjonowania sądów w Galicji i na Śląsku Cieszyńskim. Ten ostatni był częścią apelacji katowickiej, która, jak z tego wynika, posiadała wyjątkową strukturę. Oto w jednym okręgu apelacyjnym obowiązywały dwa odrębne systemy prawne, pruski w części górnośląskiej i austriacki w cieszyńskiej. Podobieństwo niemieckiej i austriackiej struktury sądownictwa zadecydowało o utworzeniu w Galicji identycznej jak w dzielnicy pruskiej struktury polskich sądów. W pierwszej instancji orzekały tu więc sądy powiatowe. Sądem odwoławczym, a niekiedy pierwszej instancji był sąd okręgowy. Odwołania od wyroków sądów okręgowych orzeczone w pierwszej instancji trafiały do właściwego sądu apelacyjnego ${ }^{14}$.

Zróżnicowanie, o którym tu mowa, utrzymało się aż do 1929 roku - 1 stycznia tego roku weszły w życie przepisy rozporządzenia Prezydenta RP z 6 lutego 1928 roku zawierającego Prawo o ustroju sądów powszechnych ${ }^{15}$. Tym samym dobiegły końca prace ustawodawcze poświęcone ujednoliceniu polskiego systemu sądownictwa. Prowadzono je początkowo w ramach Komisji Kodyfikacyjnej. Do przewrotu majowego ich tempo było raczej wolne, gdyż członkowie Komisji w toku długich

${ }^{13}$ A. Korobowicz, Sadownicy Królestwa Polskiego w wymiarze sprawiedliwości odrodzonej Polski w pierwszych latach niepodległości [w:] Historia integra. Księga pamiątkowa ofiarowana prof. Stanisławowi Salmonowiczowi w siedemdziesięciolecie urodzin, red. D. Janicka, R. Łaszewski, Torun 2001, s. 161-187.

${ }^{14}$ B. Stelmachowski, Rzut oka na ustrój sqdownictwa i postępowanie cywilne na ziemiach zachodnich oraz na Górnym Ślasku [w:] Encyklopedia prawa obowiazującego w Polsce, cz. 5: Zarys ustroju sądownictwa i postępowania cywilnego, red. A. Peretiatkowicz, Poznań 1926, s. 33-37; S. Gołąb, Organizacja sądów powszechnych. Opracowana systematycznie z uwzględnieniem rozwoju historycznego, sądownictwa szczególnego oraz ustroju adwokatury, prokuratorii generalnej i notariatu, Kraków 1938, s. 54-63.

${ }^{15}$ Dz.U. 1928, nr 12, poz. 93. 
akademickich debat próbowali rozstrzygać kwestie silnie różnicujące środowisko sędziowskie. Od 1926 roku inicjatywę w tym zakresie przejęło ministerstwo sprawiedliwości, personalnie zaś proces tworzenia nowego prawa koordynował ówczesny minister Stanisław Car. Przyspieszenie tempa prac unifikacyjnych wynikało również z uproszczenia drogi legislacyjnej. Nowe prawo nie było procedowane w Sejmie, lecz ujrzało światło dzienne jako rozporządzenie z mocą ustawy. Wśród wielu nowych rozwiązań wskażmy na unifikację dotychczas zróżnicowanej struktury sądów. Zlikwidowano sądy pokoju oraz sądy powiatowe. Na ich miejsce pojawiły się sądy grodzkie. Instancja odwoławcza realizowana w sądach okręgowych lub apelacyjnych pozostała bez zmian. Finalizacją procesu unifikacji wymiaru sprawiedliwości stało się uchwalenie wspólnych przepisów proceduralnych w postaci kodeksu postępowania karnego (w 1928 r.) oraz kodeksu postępowania cywilnego (1930 r. $)^{16}$.

Osiągnięcie celu, którym było ujednolicenie przepisów o ustroju sądownictwa, traktowano jako niewątpliwy sukces państwa polskiego. Podkreślano na przykład rolę tego aktu prawnego w zacieraniu różnic dzielnicowych i integrowaniu państwa. Satysfakcję osłabiało jednak przekonanie, iż nowy akt prawny przyczynił się równocześnie do osłabienia niezależności sądów i niezawisłości sędziowskiej. Zamach na konstytucyjną rolę wymiaru sprawiedliwości dostrzegano między innymi w procedurze przenoszenia sędziego na inne miejsce służbowe. Taką decyzję odbierano zwykle jako formę szykany, zważywszy na związane z przenosinami trudności finansowe, logistyczne i mieszkaniowe. Przyznanie w rozporządzeniu takiej kompetencji ministrowi sprawiedliwości nie było ewenementem, jednak prawo zastosowania go z bardzo ogólnie określonych przyczyn, na przykład dla dobra wymiaru sprawiedliwości i z uwagi na powagę stanowiska sędziowskiego, dawało władzy wykonawczej instrument skutecznego wpływania na postawy sędziów. Potencjalnie jeszcze groźniejszym narzędziem mogło być przymusowe przeniesienie sędziego w stan spoczynku $\mathrm{z}$ równie nieprecyzyjnie określonych powodów, między innymi z uwagi na zmiany w organizacji sądów. Sformułowania łatwo poddające się różnorakim interpretacjom dawały ministrowi istotny oręż pozwalający korygować postawy sędziów niezgodne $\mathrm{z}$ interesem sanacji. $Z$ tego powodu wymiar sprawiedliwości ocenił je jako ewidentny przykład naruszenia zasady niezawisłości sędziowskiej. Minister zyskał także duży wpływ na nominacje sędziowskie, a zwłaszcza na obsadę stanowisk kierowniczych w sądach. Związane to było z przekształceniem roli organów kolegialnych, współuczestniczących przy podejmowaniu decyzji personalnych. Prawo o ustroju sądów powszechnych zmniejszyło zakres kompetencji Zgromadzenia Ogólnego, mającego wybitnie samorządowy charakter i będącego wyrazicielem opinii sędziów pracujących w danej placówce, na rzecz Kolegiów Administracyjnych, podporządkowanych władzy wykonawczej. Jeszcze jeden zarzut formułowany wówczas dotyczył stworzenia możliwości przechodzenia do sądownictwa powszechnego dotychczasowych

${ }^{16}$ M. Mohyluk, Prawo o ustroju sąów powszechnych w pracach Komisji Kodyfikacyjnej II Rzeczypospolitej, Białystok 2004, s. 146-159; A. Machnikowska, Wymiar sprawiedliwości w II Rzeczypospolitej - wielkie zamierzenia, trudne rozstrzygnięcia [w:] Na szlakach niepodległej. Polska myśl polityczna i prawna w latach 1918-1939, red. M. Marszał, M. Sadowski, Wrocław 2009, s. 242-243. 
sędziów wojskowych. Uważano ich za wyrazicieli woli Marszałka Józefa Piłsudskiego i jego zaplecza politycznego. Ten zarzut $\mathrm{w}$ praktyce jednak się nie potwierdził. Podejmowanie pracy w sądach powszechnych przez sędziów wojskowych miało marginalny charakter ${ }^{17}$.

Na próby podporządkowania wymiaru sprawiedliwości władzy politycznej, jakich dokonywano po wejściu w życie prawa o ustroju sądów powszechnych, większość środowiska sędziowskiego zareagowała sprzeciwem. Taką opinię podzielały również osoby piastujące najwyższe stanowiska w hierarchii wymiaru sprawiedliwości. Skoro zaś władze sanacyjne także nie chciały okazać słabości, konflikt musiał przynieść wiele spektakularnych dymisji. Oprócz już wymienionego pierwszego prezesa Sądu Najwyższego, W. Seydy, ze względu na antysanacyjne przekonania swe stanowiska stracili między innymi Aleksander Mogilnicki - prezes Izby Karnej Sądu Najwyższego, Ignacy Kondratowicz - sędzia Sądu Najwyższego, Tadeusz Stark prezes Sądu Apelacyjnego w Katowicach. Ich miejsca zajęli prawnicy wykazujący się większą tolerancją dla postępowania władz. Spór, którego efektem były częste nowelizacje prawa o ustroju sądów powszechnych, mające charakter liberalizujący (jak np. nowelizacja z 4 marca $1929 \mathrm{r}^{18}$ ), względnie, przeciwnie, radykalizujące dotychczasowy stan prawny (jak np. nowelizacja z 23 sierpnia 1932 r. ${ }^{19}$ ), trwał nieprzerwanie aż do wybuchu II wojny światowej. Jego intensywność wzrosła jeszcze bardziej po uchwaleniu konstytucji kwietniowej. Znikły bowiem dotychczasowe, konstytucyjne gwarancje niezawisłości, a na to miejsce pojawiło się podporządkowanie sądów, podobnie jak i wielu innych instytucji władzy publicznej zwierzchnictwu prezydenta. Decydował o tym art. 3 ustawy zasadniczej. W efekcie sędziowie stali się jedną z grup najsilniej kontestujących władzę sanacji, czego przykładem były liczne i bardzo krytyczne w tonie artykuły publikowane w sędziowskiej prasie. Oczywiście zbytnią generalizacją byłoby stwierdzenie, iż ogół tego środowiska występował przeciw rządom sanacyjnym. W latach 30., między innymi w wyniku polityki personalnej prowadzonej przez kolejnych ministrów sprawiedliwości, zaczęła zwiększać się także wśród sędziów grupa zwolenników obozu rządzącego. Nigdy nie zdominowała ona jednak liczebnie całego środowiska, powodowała jedynie jego dezintegrację i ostre niekiedy konflikty wewnętrzne, ocierające się wręcz o zawodowy ostracyzm. Za przykład takiej sytuacji może służyć akcja wysyłania do prezesów sądów apelacyjnych anonimowych przesyłek zawierających symboliczne zawiadomienia o śmierci „na polu hańby” sędziów orzekających po myśli władz w procesie brzeskim, Klemensa Hermanowskiego oraz Jana Rykaczewskiego ${ }^{20}$.

17 G. Ławnikowicz, Sędziowie w autorytarnej Polsce, „Krajowa Rada Sądownictwa” 2016, z. 2, s. 12-17; L. Krzy ża now sk i, Rola i miejsce zasady niezawistości sędziowskiej w warunkach polskiego autorytaryzmu [w:] Silna demokracja w silnym państwie. Koncepcje reformy ustroju politycznego państwa w publicystyce politycznej XX wieku, red. J. Faryś, T. Sikorski, P. Słowiński, Gorzów Wielkopolski 2007, s. 321.

${ }_{18}$ Dz.U. 1930, nr 5, poz. 43.

19 Dz.U. 1932, nr 73, poz. 661.

${ }^{20}$ G. Ławnikowicz, Idea niezawisłości sędziowskiej w porządku prawnym i myśli prawniczej II Rzeczypospolitej, Toruń 2009, s. 320-383; P. Kierończyk, Blaski i cienie sadownictwa międzywojennego, czyli kilka uwag o wymiarze sprawiedliwości II Rzeczypospolitej [w:] Trzecia władza. 
Za swoisty instrument kształtowania politycznej postawy sędziów opinia publiczna uznawała również niedostateczny stan uposażeń sędziowskich. Jakkolwiek należy się zgodzić z tezą, iż wynagrodzenie sędziów stało na niskim poziomie, trudno jednak dostrzec w tym elemencie celową politykę sanacji. Skromną płacę otrzymywali sędziowie w zasadzie od początku okresu międzywojennego, władzy sanacyjnej zaś zarzucić można co najwyżej, że nie zajęła się należycie tą kwestią. W latach 1918-1939 dwukrotnie, za pomocą ustaw uposażeniowych, określano wysokość wynagrodzenia na poszczególnych stanowiskach sędziowskich. W obu przypadkach rozstrzygnięcia płacowe środowisko sędziowskie przyjmowało z rozczarowaniem, wskazując na negatywne konsekwencje finansowej zapaści. Sędziowie byli najgorzej uposażoną grupą spośród zawodów prawniczych. W 1930 roku rozpoczynający pracę samotny sędzia grodzki mógł liczyć na 371 zł, co wymuszało bardzo oszczędną egzystencję. Nieco wyższe wynagrodzenie otrzymywano za pracę w sądzie okręgowym (przeciętnie $600 \mathrm{zl}$ ), apelacyjnym (przeciętnie $800 \mathrm{zł}$ ), a elita finansowa wśród sędziów, zatrudniona w Sądzie Najwyższym, mogła liczyć na płacę przekraczającą 1000 zł. Dochody sędziów, zwłaszcza pracujących w sądach pierwszej instancji, nie mogły równać się z wynagrodzeniem adwokata czy notariusza. Podobnie skromne uposażenie otrzymywali jedynie prokuratorzy. Jest to oczywiście uwaga o charakterze uogólniającym (np. adwokaci na prowincji często musieli zadowalać się wynagrodzeniem niewiele wyższym od sędziowskiego), niemniej utrwalone w świadomości sędziów przekonanie o wyższości ekonomicznej prawniczych wolnych zawodów powodowało, iż chętnie opuszczano sądownictwo na rzecz adwokatury lub notariatu. Przez większość okresu międzywojennego wywoływało to znaczące problemy organizacyjne. Przeciętne dochody sędziów były wyraźnie niższe od uzyskiwanych przez oficerów wojska polskiego, a nawet przez nauczycieli pracujących w renomowanych szkołach średnich. Wywoływało to protesty środowiskowe, przy okazji których podkreślano, że skoro sędziom nie wolno podejmować dodatkowej pracy zarobkowej, ich uposażenie musi wystarczyć na egzystencję godną reprezentanta trzeciej władzy. Mimo licznych apeli, czasem utrzymanych w dramatycznym tonie, sytuacja bytowa sędziów nie poprawiła się aż do końca okresu międzywojennego ${ }^{21}$.

Wśród wielu zmian, jakie wprowadzono w prawie o ustroju sądów powszechnych, przynajmniej jedna zyskała z czasem historyczny wręcz wymiar, choć samo jej wejście w życie nie zostało odnotowane z właściwą uwagą. Wspomniany akt prawny, po raz pierwszy w dziejach Polski, dopuszczał kobiety do wykonywania zawodu sędziego. Kwestia ta podzieliła autorytety prawnicze, co skutkowało burzliwymi dyskusjami na forum Komisji Kodyfikacyjnej. Przeciwnicy wskazywali na społeczne skutki „rewolucyjnego", ich zdaniem, posunięcia oraz na to, iż psychika kobiet nie jest właściwa do tego, by obciążać ją kontaktami ze zdemoralizowanymi przestępcami. Zwolennicy zmiany podkreślali, że tylko w ten sposób uzyska się zgodność

Sąy i Trybunały w Polsce, Gdańsk 2008, s. 382-390; M. Materni a k-P a włow sk a, Zawód sędziego w Polsce w latach 1918-1939, „Czasopismo Prawno-Historyczne” 2011, z. 1, s. 73-80.

${ }^{21}$ Konieczność reformy uposażenia sędziów i prokuratorów, „Przegląd Sądowy” 1919, nr 4, s. 20 22; M. Wis zniew sk i, Paradoksy uposażenia sędziowskiego, „Głos Sądownictwa” 1938, nr 2, s. 130 132; M. Materniak-Pawłowska, Zawód..., s. 107-108. 
nowego prawa z konstytucją marcową. Komisja, 13 września 1923 roku, większością zaledwie jednego głosu rekomendowała przyjęcie zasady, iż wykonywanie zawodu sędziego dozwolone jest zarówno mężczyznom, jak i kobietom. Projekt procedowany przez Komisję Kodyfikacyjną ostatecznie nie stał się, jak wiadomo, obowiązującym prawem, niemniej jednak zaakceptowane tam prawidło przeniesiono do tekstu prezydenckiego rozporządzenia. Jego wejście w życie, co oczywiste, nie zmieniło mentalności sędziów mężczyzn, a to oni decydowali o nominacjach sędziowskich. W konsekwencji do końca okresu międzywojennego zaledwie osiem kobiet uzyskało pełne prawo orzekania w sądach. Pierwszą, która wystąpiła w tej roli, była Wanda Grabińska, zatrudniona w warszawskim sądzie dla nieletnich. Ten typ sądownictwa wydawał się bowiem decydentom jedynym, w którym kobiety ostatecznie mogły znaleźć swe miejsce. Dodajmy, że nie było ani jednej kobiety prokuratora lub notariusza i jedynie zawód adwokata otwarty był dla pań w większym stopniu, aczkolwiek i tam ich odsetek do imponujących nie należał ${ }^{22}$.

Niepowodzenie, jakie było udziałem bardzo wielu kobiet starających się o zatrudnienie w charakterze sędziego, wynikało z konserwatyzmu osób zajmujących wyższe stanowiska w hierarchii wymiaru sprawiedliwości. Nie była to wszakże jedyna przyczyna. Należy wziąć pod uwagę również i to, że opisywane tu zjawisko przybrało na sile w drugiej połowie lat 30., gdy prawników z zaliczonym egzaminem sędziowskim było znacznie więcej niż wolnych etatów. Sytuacja zmieniła się pod tym względem diametralnie w okresie międzywojennym. U zarania II Rzeczypospolitej polskich sędziów brakowało. Wówczas niemal każdy, kto dysponował stosownymi uprawnieniami, otrzymywał angaż natychmiast, a nawet mógł wybrać sobie miejsce pracy. Z czasem, gdy uniwersytety opuściło pierwsze pokolenie prawników wykształconych już w Polsce, wszystkie wolne miejsca zostały zajęte, a w latach 30. dała się zauważyć „nadprodukcja” sędziów. Egzaminowani aplikanci zwykle 2-3 lata czekali na etat asesora, a następnie, nie krócej, na posadę sędziego. Stan taki generował wiele negatywnych zjawisk, nie tylko eliminację kobiet z grona kandydatów. Ze starań o dostęp do zawodu sędziego rezygnowały osoby pochodzące z uboższych domów, gdyż nie stać ich było na wieloletnie oczekiwanie na opróżnienie się urzędu. Niektórzy sięgali po zakazane, ale niekiedy skuteczne metody zwiększania własnych szans, np. korupcję lub wsparcie polityczne. Z drugiej strony warto zauważyć także pozytywny skutek wynikający z objęcia urzędów sędziowskich przez młode pokolenie Polaków. Dawali oni gwarancję, iż sądy nie staną się instrumentem antynarodowych działań, jak to zdarzało się często w okresie zaborów ${ }^{23}$.

Przedstawione powyżej, z konieczności mocno skrótowe refleksje, nad międzywojennym sądownictwem powszechnym skłaniają do wniosku, iż jego jednoznaczna ocena jest bardzo trudna. Składają się na nią bowiem zarówno sukcesy, jak

${ }^{22}$ L. Krzyżan owski, W. Okniński, Temida wyemancypowana? Stownik biograficzny kobietsędziów, asesorów i egzaminowanych aplikantów w międzywojennym sądownictwie polskim, Sopot 2018, s. 7-31; M. S ty pułk ow ska, Trudna droga kobiet do wykonywania zawodów prawniczych, „Palestra” 1994, nr 38/9-10, s. 139-149; M. Mohyluk, op. cit., s. 143-146.

${ }^{23}$ W. Dy mek, O typ polskiego sędziego, „Głos Sądownictwa” 1930, nr 7-8, s. 421; L. W ój cik, Realizacja unifikacji polskiego wymiaru sprawiedliwości, „Głos Sądownictwa” 1937, nr 10, s. 753-754. 
i niepowodzenia. W pierwszej grupie znaleźć się musi zakończona powodzeniem unifikacja sądownictwa. Mimo ogromnych różnic w metodach orzekania, a zwłaszcza w przyzwyczajeniach związanych z tą pracą, udało się stworzyć ogólnopolski model sędziego. Zaczął on niepodzielnie panować w sądach. Po raz pierwszy w takiej skali dostęp do orzekania uzyskała polska młodzież, w tym kobiety. Prawda, że nieliczne, ale $\mathrm{w}$ innych krajach europejskich w tym czasie sytuacja przedstawiała się podobnie. Były i ciemniejsze strony funkcjonowania sądów. Polityczne naciski, zwłaszcza po 1926 roku, stawiały pod znakiem zapytania respektowanie niezawisłości sędziowskiej. Wielu sędziów z tego powodu zostało zmuszonych do przedwczesnego odejścia z zawodu. Nie udało się także rozwiązać bolączek finansowych. Niektórzy sędziowie, mocno spauperyzowani, nie ukrywali swego rozgoryczenia, iż ojczyzna nie darzy ich pracy właściwym szacunkiem. Ten mocno zróżnicowany bilans sądownictwa nie odbiegał od obrazu innych dziedzin aktywności państwa, kreślonego zarówno z użyciem jasnych, jak i ciemnych barw.

\section{BIBLIOGRAFIA}

\section{Źródła archiwalne}

Archiwum Akt Nowych, Tymczasowa Rada Stanu.

Archiwum Narodowe w Krakowie, Sąd Apelacyjny w Krakowie.

Archiwum Państwowe w Katowicach, Naczelna Rada Ludowa.

Archiwum Państwowe w Poznaniu, Sąd Apelacyjny w Poznaniu.

\section{Źródła drukowane}

Dziennik Praw Państwa Polskiego 1918-1919.

Dziennik Urzędowy Departamentu Sprawiedliwości 1917.

Dziennik Ustaw Rzeczypospolitej Polskiej 1928, 1930, 1932, 1938.

\section{Opracowania}

Cybuls ki B., Geneza polskiego sądownictwa na Górnym Śląsku (1920-1922), „Studia Śląskie" 1990, t. 98.

Cybulsk i B., Pomoc Małopolski i Wielkopolski w tworzeniu apelacji ślaskiej (1920-1922), „Acta Universitatis Wratislaviensis” nr 823, Prawo, CXXXVII, Wrocław 1986.

Cybulski B., Sąd Najwyższy w latach 1917-1919, „Acta Universitatis Wratislaviensis” nr 2501, Prawo, CCLXXXV, Wrocław 2003.

Dymek W., O typ polskiego sędziego, „Głos Sądownictwa” 1930, nr 7-8.

F e do rowicz Z., Wypisy do nauki o Polsce współczesnej, Wilno 1923. 
Gołąb S., Organizacja sądów powszechnych. Opracowana systematycznie z uwzględnieniem rozwoju historycznego, sądownictwa szczególnego oraz ustroju adwokatury, prokuratorii generalnej i notariatu, Kraków 1938.

Ki eroń c zyk P., Blaski i cienie sądownictwa międzywojennego, czyli kilka uwag o wymiarze sprawiedliwości II Rzeczypospolitej [w:] Trzecia władza. Sąy i Trybunały w Polsce, red. A. Szmyt, Gdańsk 2008.

Konieczność reformy uposażenia sędziów i prokuratorów, „Przegląd Sądowy” 1919, nr 4.

Korobowicz A., Sądownicy Królestwa Polskiego w wymiarze sprawiedliwości odrodzonej Polski w pierwszych latach niepodległości [w:] Historia integra. Księga pamiątkowa ofiarowana prof. Stanisławowi Salmonowiczowi w siedemdziesięciolecie urodzin, red. D. Janicka, R. Łaszewski, Toruń 2001.

Krzyżanowski L., Rola i miejsce zasady niezawistości sędziowskiej w warunkach polskiego autorytaryzmu [w:] Silna demokracja w silnym państwie. Koncepcje reformy ustroju politycznego państwa w publicystyce politycznej XX wieku, red. J. F aryś, T. S i korski, P. Słowiński, Gorzów Wielkopolski 2007.

Krzyżanowski L., Sędziowie w II Rzeczypospolitej. Okręgi apelacyjne: krakowski i katowicki, Katowice 2011.

Krzyżan ow ski L., Okniński W., Temida wyemancypowana? Słownik biograficzny kobiet - sędziów, asesorów i egzaminowanych aplikantów $w$ międzywojennym sądownictwie polskim, Sopot 2018.

Krzy ża now sk i L., Właczanie krakowskiego okręgu sądowego do struktur wymiaru sprawiedliwości II Rzeczypospolitej. Geneza, przebieg i skutki, „Krajowa Rada Sądownictwa” $2017, \mathrm{nr} 3$.

Ławnikowicz G., Idea niezawisłości sędziowskiej w porządku prawnym i myśli prawniczej II Rzeczypospolitej, Toruń 2009.

Ławnik ow ic z G., Sędziowie w autorytarnej Polsce, „Krajowa Rada Sądownictwa” 2016, z. 2.

Machnikowska A., Wymiar sprawiedliwości w II Rzeczypospolitej-wielkie zamierzenia, trudne rozstrzygnięcia [w:] Na szlakach niepodległej. Polska myśl polityczna i prawna w latach 1918-1939, red. M. Mars zał, M. S a d ow ski, Wrocław 2009.

Materniak-Pawłowska M., Departament Sprawiedliwości Tymczasowej Rady Stanu i początki Ministerstwa Sprawiedliwości (luty 1917-październik 1918), „Czasopismo Prawno-Historyczne" 2006, z. 2.

Materniak-P awłow ska M., Sądy Królewsko-Polskie (1917-1918), „Czasopismo Prawno-Historyczne" 2007, z. 1.

Materniak-Pawłowska M., Ustrój sądownictwa powszechnego w II Rzeczypospolitej, Poznań 2003.

Materniak-P awłow s ka M., Zawód sędziego w Polsce w latach 1918-1939, „Czasopismo Prawno-Historyczne" 2011, z. 1.

Mohyluk M., Prawo o ustroju sądów powszechnych w pracach Komisji Kodyfikacyjnej II Rzeczypospolitej, Białystok 2004.

Petrus ew i z K., Dziesięciolecie sądownictwa polskiego na Ziemiach Wschodnich, Wilno 1929.

Wznowienie sądownictwa państwowego polskiego (pięciolecie 1917-1922), Warszawa 1923.

Pietrzak M., Sąd Najwyższy w II Rzeczypospolitej, „Czasopismo Prawno-Historyczne” 1981, z. 1 .

R app a port E.S., Pierwociny polskiego sadownictwa państwowego (1916-1917) (Szkic historyczny), „Demokratyczny Przegląd Prawniczy” 1947, nr 9.

Sądownictwo na Spiszu i Orawie, „Przegląd Sądowy” 1920, nr 12. 
Stelmachow ski B., Rzut oka na ustrój sadownictwa i postępowanie cywilne na ziemiach zachodnich oraz na Górnym Śląsk [w:] Encyklopedia prawa obowiązującego w Polsce, red. A. P e retiatkow ic z, cz. 5. Zarys ustroju sadownictwa i postępowania cywilnego, Poznań 1926.

Stypułkowska M., Trudna droga kobiet do wykonywania zawodów prawniczych, „Palestra" 1994, nr 38/9-10.

Wi szniew ski M., Paradoksy uposażenia sędziowskiego, „Głos Sądownictwa” 1938, nr 2.

W ój c ik L., Realizacja unifikacji polskiego wymiaru sprawiedliwości, „Głos Sądownictwa” 1937, nr 10.

Zając zk ow ski T., Szkic historyczny organizacji sądownictwa polskiego w bytej dzielnicy pruskiej od czasów rewolucyjnych 1918 r. [w:] Zbiór rozporządzeń i okólników Ministerstwa bytej Dzielnicy Pruskiej z roku 1920 majacych znaczenie dla wymiaru sprawiedliwości, Poznań 1921. 